Supporting Information for:

\title{
Nickel(II) Cyclen Complexes Bearing Ancillary Amide Appendages for the Electrocatalytic Reduction of $\mathrm{CO}_{2}$
}

Tian Qiu, Glenn P. A. Yap, and Joel Rosenthal ${ }^{*}$

joelr@udel.edu

Department of Chemistry and Biochemistry, University of Delaware, Newark, DE 19716 


\section{Experimental Methods}

\section{General Procedures}

Reactions that required an inert atmosphere were performed in a $\mathrm{N}_{2}$ filled glove box, or under a positive pressure of $\mathrm{N}_{2}$ on a manifold using standard Schlenk techniques. Air and moisture sensitive reagents were transferred using standard syringe or cannula techniques. ${ }^{1}$ All glassware was dried at $140{ }^{\circ} \mathrm{C}$ for at least 3 hours.

Reagents and solvents were purchased from Sigma Aldrich, Acros, Fisher, Strem, or Cambridge Isotopes Laboratories and used as received unless otherwise noted. Solvents for synthesis were reagent grade or better. Anhydrous solvents were dried by passage through activated alumina and then stored over $4 \AA$ molecular sieves prior to use. $^{2}$

\section{Materials}

Tetrabutylammonium hexafluorophosphate $\left(\mathrm{TBAPF}_{6}\right)$ was purchased from Tokyo Chemical Industry Co. LTD, recrystallized from ethyl alcohol, and dried under vacuum at $40{ }^{\circ} \mathrm{C}$ for at least one week prior to use. Cyclen (1,4,7,10-tetraazacyclododecane) was purchased from Strem Chemicals Inc. The dimethylcyclen (1,7-dimethyl-1,4,7,10tetraazacyclododecane) ligand (2) was prepared from cyclen according to previously reported procedures. ${ }^{3-5}$ The ligand 1,4,7-trimethyl-1,4,7,10-tetraazacyclododecane (4) was prepared from cyclen following previously reported procedures. ${ }^{6} \mathrm{~N}$-tert-butyl-2chloroacetamide (1b) ${ }^{7}$ was also prepared according to previously reported procedures. ${ }^{8}$

\section{Physical Methods}

\section{Nuclear Magnetic Resonance (NMR) Spectroscopy}

${ }^{1} \mathrm{H}$ NMR and ${ }^{13} \mathrm{C}$ NMR spectra were recorded at $25^{\circ} \mathrm{C}$ on a Bruker AV400 (400 $\mathrm{MHz})$ or an AV600 (600 MHz) spectrometer. Proton spectra are referenced to the residual proton resonance of the deuterated solvent $\left(\mathrm{CDCl}_{3}=\delta 7.26\right)$ and carbon spectra are 
referenced to the carbon resonances of the solvent $\left(\mathrm{CDCl}_{3}=\delta 77.23\right)$. All chemical shifts are reported using the standard $\delta$ notation in parts-per-million; positive chemical shifts are to higher frequency from the given reference.

\section{Mass Spectrometry and Elemental Analyses}

LR-EI-MS data was obtained using an Agilent 5973 GC-MS. LR-ESI MS data was obtained using a LCQ Advantage from Thermofinnigan. High-resolution mass spectrometry analyses were either performed by the Mass Spectrometry Laboratory within the Department of Chemistry and Biochemistry at University of Delaware or at the University of Illinois at Urbana-Champaign. Elemental analyses were performed by Intertek QTI, Whitehouse, NJ., or Robertson Microlit Laboratories, Inc. Ledgewood, NJ.

\section{X-ray Crystallography}

Crystals were mounted using viscous oil onto a plastic mesh and cooled to the data collection temperature. Data were collected on a Bruker-AXS APEX II DUO CCD or on a Smart APEX diffractometer with Mo-Ka radiation $(\lambda=0.71073 \AA)$ monochromated with graphite. Unit cell parameters were obtained from 36 data frames, $0.5^{\circ} \omega$, from three different sections of the Ewald sphere. The unit-cell parameters, equivalent reflections, and systematic absences in the diffraction data are consistent, uniquely, with $P 2{ }_{1} / c$ for [Ni(DMCy $\left.\left.{ }^{2 C_{6 F 5}}\right)\right]\left(\mathrm{PF}_{6}\right)_{2}$, [Ni(DMCy $\left.\left.{ }^{\mathrm{Mes}}\right)(\mathrm{Cl})\right]\left(\mathrm{PF}_{6}\right)$ and $\left[\mathrm{Ni}\left(\mathrm{TrMCy}^{\mathrm{Mes}}\right)(\mathrm{Cl})\right] \mathrm{Cl}$; uniquely, for $P 2_{1} / n$ for $\left[\mathrm{Ni}\left(\mathrm{DMCy}^{2 \mathrm{Mes}}\right)\right]\left(\mathrm{PF}_{6}\right)_{2}$ and $\left[\mathrm{Ni}\left(\mathrm{DMCy}^{2 \mathrm{CF}_{3}}\right)\right]\left(\mathrm{PF}_{6}\right)_{2}$; and for $14,1-4$, and $14 / \mathrm{m}$ for $\left[\mathrm{Ni}\left(\mathrm{DMCy}^{2 \mathrm{tBu}}\right)\right]\left(\mathrm{PF}_{6}\right)_{2}$. The occupancy of 8 and the presence of a molecular mirror are consistent with the selected spacegroup $14 / m$ for the $\left[\mathrm{Ni}\left(\mathrm{DMCy}^{2 \mathrm{tBu}}\right)\right]\left(\mathrm{PF}_{6}\right)_{2}$ complex. No symmetry higher than triclinic was observed for the DMCy ${ }^{2 M e s}$ ligand and solution in the centrosymmetric space group option yielded chemically reasonable and computationally stable results of refinement. The data sets were treated with multi-scan absorption corrections (Apex3 software suite, Madison, WI, 2015). The structures were solved using 
direct methods and refined with full-matrix, least-squares procedures on $F^{2} .9$ These structures display varying levels of disorder associated with the outersphere $\mathrm{PF}_{6}{ }^{-}$counter ions and cocrystallized acetonitrile solvent. Two ion pairs were located in the asymmetric unit of $\left[\mathrm{Ni}\left(\mathrm{DMCy}^{2 \mathrm{CF}^{65}}\right)\right]\left(\mathrm{PF}_{6}\right)_{2}$. The data for $\left[\mathrm{Ni}\left(\mathrm{DMCy}^{2 \mathrm{Mes}}\right)\right]\left(\mathrm{PF}_{6}\right)_{2}$, $\left[\mathrm{Ni}\left(\mathrm{DMCy}^{2 \mathrm{tBu}}\right)\right]\left(\mathrm{PF}_{6}\right)_{2}$, and $\left[\mathrm{Ni}\left(\mathrm{DMCy}^{2 \mathrm{C}_{65}}\right)\right]\left(\mathrm{PF}_{6}\right)_{2}$ were treated with Squeeze to model disordered solvent molecules as diffused contributions. ${ }^{10}$ The $\mathrm{PF}_{6}{ }^{-}$counter ions in $\left.\mathbf{N i}\left(\mathrm{DMCy}^{2 \mathrm{CF}}\right)^{2}\right)\left(\mathrm{PF}_{6}\right)_{2}$ were treated with rigid bond $U$ restraints. Additionally, many of the structures display positional, and substitutional disorder: for $\mathrm{Ni}\left(\mathrm{DMCy}^{2 \mathrm{CF}}\right)^{2}\left(\mathrm{PF}_{6}\right)_{2}, 51 / 49$ and $60 / 40$ for each $\mathrm{PF}_{6}{ }^{-}$ position. The DMCy2Mes ligand structure is located on an inversion center. All nonhydrogen atoms were refined with anisotropic displacement parameters. The amide $\mathrm{H}$ atom in the DMCy ${ }^{2 M e s}$ ligand structure was located from the difference map and assigned $U_{\text {iso }}$ equal to $1.2 \mathrm{~N} U_{\text {eq. }} \mathrm{H}$-atoms were placed in calculated positions with $U_{\text {iso }}$ equal to 1.2 (1.5 for methyl $\mathrm{H}) U_{\text {eq }}$ of the attached atom. Atomic scattering factors are contained in the SHELXTL program library. The CIF files for each of the structures reported in this work have been deposited with the Cambridge Crystallographic Database as follows: under

DMCy $^{2 \mathrm{Mes}} \quad(\mathrm{CCDC} \quad 1498853) ; \quad\left[\mathrm{Ni}\left(\mathrm{DMCy}^{2 \mathrm{Mes}}\right)\right]\left(\mathrm{PF}_{6}\right)_{2} \quad(\mathrm{CCDC} \quad 1497917) ;$ $\left[\mathrm{Ni}\left(\mathrm{DMCy}^{2 \mathrm{tBu}}\right)\right]\left(\mathrm{PF}_{6}\right)_{2} \quad(\mathrm{CCDC} \quad 1497920) ; \quad\left[\mathrm{Ni}\left(\mathrm{DMCy}^{2 \mathrm{C6F5}}\right)\right]\left(\mathrm{PF}_{6}\right)_{2} \quad(\mathrm{CCDC}$ 1497921); [Ni(DMCy $\left.\left.{ }^{2 C F 3}\right)\right]\left(P_{6}\right)_{2} \quad\left(C C D C\right.$ 1497918); [Ni(DMCyMes)(CI)](PF $\left.{ }_{6}\right)$ (CCDC 1497922); $\left[\mathrm{Ni}\left(\operatorname{TrMCy}^{\mathrm{Mes}}\right)(\mathrm{Cl})\right] \mathrm{Cl}(\mathrm{CCDC}$ 1497923).

\section{Electrochemistry}

Cyclic voltammetry (CV) experiments were performed using a CHI-620D potentiostat/galvanostat using a standard three-electrode configuration. The working electrode was a polished glassy carbon electrode (GCE, $3.0 \mathrm{~mm}$ diameter, $\mathrm{CH}$ Instruments) and the auxiliary electrode was a piece of platinum wire or platinum gauze. Electrochemical potentials were measured against a silver wire pseudo reference, unless otherwise noted, with a decamethylferrocene internal standard and adjusted to saturate 
calomel electrode $(\mathrm{SCE})$ via the relation $\mathrm{Fc}^{*+} / \mathrm{Fc}^{*}=-46 \mathrm{mV}+\mathrm{SCE}$. The supporting electrolyte employed for $\mathrm{CV}$ and CPE experiments was $0.1 \mathrm{M}$ tetrabutylammonium hexafluorophosphate $\left(\mathrm{TBAPF}_{6}\right.$ ), dissolved in $\mathrm{CH}_{3} \mathrm{CN}$. The analyte concentration was 1.0 $\mathrm{mM}$, and all CV experiments were carried out using a scan rate of $100 \mathrm{mV} / \mathrm{s}$. Gases including $\mathrm{CO}_{2}$ and $\mathrm{N}_{2}$ were dried by passing through a Glass Indicating Moisture Trap $(3.5 \times 26 \mathrm{~cm})$ containing $5 \AA$ molecular sieves (Restek), and were used to deoxygenate the electrolyte solutions prior to electrochemical studies. A gentle flow of these dry gases was continually passed through the headspace of the electrochemical set up during voltammetric and electrolysis experiments.

Controlled potential electrolysis (CPE) experiments were performed in a singlecompartment cell using the same three-electrode setup employed for CV measurements. These consisted of a polished glassy carbon working electrode, a platinum mesh counter electrode, and a silver wire pseudo reference. Prior to electrolysis the solution was sparged with $\mathrm{CH}_{3} \mathrm{CN}$ saturated $\mathrm{CO}_{2}$ gas for approximately $30 \mathrm{~min}$, following which, the cell was sealed and electrolysis initiated. The headspace of the electrolysis cell was periodically sampled by manually removing $1.0 \mathrm{~mL}$ aliquots using a gas-tight syringe. These aliquots were analyzed by manual injection into a gas-sampling loop of a gas chromatograph (SRI Instruments, SRI-8610C). The sampling loop of the GC was placed in line with both a packed HayeSep D column and a packed MoleSieve 13X column. Argon (Keen, 99.999\%) was used as the GC carrier gas. The GC columns led directly to a thermal conductivity detector (TCD) to quantify hydrogen and a flame ionization detector (FID) equipped with a methanizer to quantify carbon monoxide.

The following equations were used for Faradaic Efficiency and current density calculation for the CPE experiments:

$$
\begin{gathered}
\text { Faradaic efficiency }(\mathrm{FE}) \text { for product }(\%)=\frac{\text { Product in mmol } \times 2}{\text { Total electrons passed in mmol }} \times 100 \% \\
=\frac{\left(\mathrm{PPM}_{\text {product }} \times 0.052 \times 2\right) /(82.06 \times 298)}{\text { Total charge passed }(\mathrm{C}) \times 1000 / 96500} \times 100 \%
\end{gathered}
$$


Current density for product $\left(\mathrm{mA} \cdot \mathrm{cm}^{-2}\right)=\frac{\text { Average of total current } \times 1000}{\text { Area of the electrode }\left(\mathrm{cm}^{2}\right)} \times \mathrm{FE}$ for product

where PPM product is obtained from GC analysis in parts per million, 0.052 represents the headspace volume of the electrochemical cell in liters; 2 represents the electron equivalents the substrate is reduced by; 82.06 is the ideal gas law constant in $\mathrm{cm}^{3} \cdot \mathrm{atm} \cdot \mathrm{K}^{-1} \cdot \mathrm{mol}^{-1} ; 298$ represents the temperature in $\mathrm{K} ; 96500$ represents the Faradaic constant; $0.07 \mathrm{~cm}^{2}$ is the area of the working electrode.

\section{Synthetic Protocols}

2-chloro-N-2,4,6-trimethylacetanilide (1a) A solution of 2,4,6-trimethylanaline $(1.60 \mathrm{~mL}, 0.010 \mathrm{~mol})$ in $\mathrm{DCM}(10 \mathrm{~mL})$ was mixed with aqueous $\mathrm{NaOH}(4.0 \mathrm{~mL}, 6.2 \mathrm{M})$. The mixture was cooled to $0^{\circ} \mathrm{C}$ and kept in an ice bath. The reaction mixture was stirred and chloroacetyl chloride $(1.0 \mathrm{~mL}, 0.01 \mathrm{~mol})$ was slowly added using a syringe. After the addition, the reaction was allowed to warm to room temperature and extracted with DCM $(3 \times 10 \mathrm{~mL})$. The combined organic extracts were sequentially washed with $10 \mathrm{~mL}$ of $5 \%$ aqueous $\mathrm{HCl}, 10 \mathrm{~mL}$ of saturated $\mathrm{NaHCO}_{3}$, and twice with $10 \mathrm{~mL}$ of water $(2 \times 10 \mathrm{~mL})$, and then was dried over $\mathrm{Na}_{2} \mathrm{SO}_{4}$. Removal of the solvent under vacuum yielded $1.97 \mathrm{~g}$ of the product as a white solid (Yield $=93 \%) .{ }^{1} \mathrm{H}$ NMR $\left(400 \mathrm{MHz}, \mathrm{CDCl}_{3}\right) \delta / p p m 7.78(\mathrm{~s}, 1 \mathrm{H})$, $6.92(\mathrm{~s}, 2 \mathrm{H}), 4.25(\mathrm{~s}, 2 \mathrm{H}), 2.28(\mathrm{~s}, 3 \mathrm{H}), 2.20(\mathrm{~s}, 6 \mathrm{H}) .{ }^{13} \mathrm{C}$ NMR $\left(101 \mathrm{MHz}, \mathrm{CDCl}_{3}\right) \delta / p p m$ 164.67, 137.72, 135.14, 130.09, 129.18, 42.87, 21.07, 18.28. El-MS: [M] ${ }^{+} \mathrm{m} / \mathrm{z}$ : calcd for $\mathrm{C}_{11} \mathrm{H}_{14} \mathrm{NOCl}, 211$; found 211.

2-chloro-N-3,5-bis(trifluoromethyl)acetanilide (1c). This compound was prepared from 3,5-bis(trifluoromethyl)analine $(1.45 \mathrm{~mL}, 0.010 \mathrm{~mol})$ and chloroacetyl chloride $(1.0 \mathrm{~mL}, 0.01 \mathrm{~mol})$ in $91 \%$ yield $(2.80 \mathrm{~g}, 9.3 \mathrm{mmol})$ following the same procedure that was used for 2-chloro-N-2,4,6-trimethylacetanilide (1a). ${ }^{1} \mathrm{H}$ NMR $\left(400 \mathrm{MHz}, \mathrm{CDCl}_{3}\right)$ ס/ppm 8.48 (s, 1H), 8.08 (s, 2H), 7.68 (s, 1H), 4.25 (s, 2H). ${ }^{13} \mathrm{C}$ NMR $\left(101 \mathrm{MHz}, \mathrm{CDCl}_{3}\right)$ ठ/ppm 164.44, 138.21, 132.74 (q, $J=33.7 \mathrm{~Hz}), 123.05$ (q, $J=272.9 \mathrm{~Hz}), 118.92$ (d, $J=$ 
3.2 Hz), $118.88-118.60(\mathrm{~m}), 42.83$. El-MS: [M] ${ }^{+} \mathrm{m} / \mathrm{z}$ : calcd for $\mathrm{C}_{10} \mathrm{H}_{6} \mathrm{NOClF}_{6}, 305$; found 305.

2-chloro-N-2,3,4,5,6-pentafluoroacetanilide (1d). This compound was prepared from 2,3,4,5,6-pentafluoroanaline $(1.85 \mathrm{~mL}, 0.010 \mathrm{~mol})$ and chloroacetyl chloride $(1.0 \mathrm{~mL}$, $0.01 \mathrm{~mol})$ in $40 \%$ yield $(1.05 \mathrm{~g}, 4.00 \mathrm{mmol})$ following the same procedure that was used for 2-chloro-N-2,4,6-trimethylacetanilide (1a). ${ }^{1} \mathrm{H}$ NMR $\left(400 \mathrm{MHz}, \mathrm{CDCl}_{3}\right.$ ) $\delta / p p m ~ 7.84$ (s, 1H), 4.28 (s, 2H). ${ }^{13} \mathrm{C}$ NMR (101 MHz, $\left.\mathrm{CDCl}_{3}\right) \delta / p p m 164.69,143.30$ (d, J = $\left.247.9 \mathrm{~Hz}\right)$, 140.65 (d, $J=252.5 \mathrm{~Hz}$ ), 137.99 (d, $J=256.4 \mathrm{~Hz}), 110.78$ (td, $J=13.3,3.0 \mathrm{~Hz}$ ), 42.48. El-MS: $[M]^{+} \mathrm{m} / \mathrm{z}$ : calcd for $\mathrm{C}_{8} \mathrm{H}_{3} \mathrm{NOClF}_{5}, 259$; found 259 .

\section{1,7-dimethyl-4,10-bis(N-2,4,6-trimethylacetanilide)-1,4,7,10-tetraazacyclo-}

dodecane (DMCy ${ }^{2 \mathrm{Mes}}$ ). 1,7-dimethyl-1,4,7,10-tetraazacyclododecane (2) ${ }^{3-5}$ (200 mg, $1.00 \mathrm{mmol}$ ) and 2-chloro- $\mathrm{N}-2,4,6$-trimethylacetanilide (1a) (848 mg, $4.00 \mathrm{mmol}$ ) were combined with $\mathrm{K}_{2} \mathrm{CO}_{3}(414 \mathrm{mg}, 3.00 \mathrm{mmol})$ and $\mathrm{KI}(664 \mathrm{mg}, 4.00 \mathrm{mmol})$ in $30 \mathrm{~mL}$ of $\mathrm{CH}_{3} \mathrm{OH}$. The resulting mixture was heated at reflux for $12 \mathrm{~h}$ and then filtered through sintered glass to remove any solid materials. Distilled water $(100 \mathrm{~mL})$ was added to the filtered solution and aliquots of $20 \%$ aqueous $\mathrm{HCl}$ were added until $\mathrm{pH}<2$. The resulting solution was extracted three times with $30 \mathrm{~mL}$ of $\mathrm{Et}_{2} \mathrm{O}$. Aliquots of $6 \mathrm{M} \mathrm{NaOH}$ were then added to the aqueous layer until $\mathrm{pH}>12$. The aqueous layer was then extracted with $\mathrm{CHCl}_{3}(7 \times 30 \mathrm{~mL})$ and the combined extracts were dried over $\mathrm{Na}_{2} \mathrm{SO}_{4}$. Removal of the solvent by rotary evaporation delivered the crude product as a yellow oil. Aliquots of $\mathrm{CH}_{3} \mathrm{CN}(0.5 \mathrm{~mL})$ were added to the crude oil which induced precipitation of a white solid, which was isolated and dried under vacuum to deliver $308 \mathrm{mg}$ of the desired product

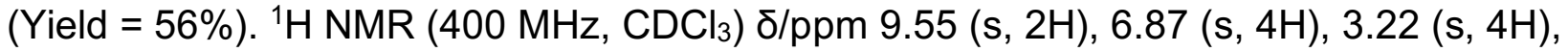
$2.80-2.74(\mathrm{~m}, 8 \mathrm{H}), 2.61-2.55(\mathrm{~m}, 8 \mathrm{H}), 2.26(\mathrm{~s}, 6 \mathrm{H}), 2.17(\mathrm{~s}, 12 \mathrm{H}), 2.14(\mathrm{~s}, 6 \mathrm{H}) .{ }^{13} \mathrm{C}$

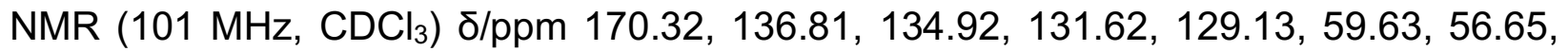
55.61, 44.32, 21.09, 18.65. HR-ESI-MS: $[\mathrm{M}+\mathrm{H}]^{+} \mathrm{m} / \mathrm{z}$ : calcd for $\mathrm{C}_{32} \mathrm{H}_{51} \mathrm{~N}_{6} \mathrm{O}_{2}, 551.4073$; found 551.4067 . 


\section{1,7-dimethyl-4,10-bis( $N$-tert-butylacetamide)-1,4,7,10-tetraazacyclo-}

dodecane (DMCy $\left.{ }^{2 t B u}\right)$. This compound was prepared from 1,7-dimethyl-1,4,7,10tetraazacyclododecane $(2)^{3-5}(200 \mathrm{mg}, 1.00 \mathrm{mmol})$ and $\mathrm{N}$-tert-butyl-2-chloroacetamide (1b) $(598 \mathrm{mg}, 4.00 \mathrm{mmol}$ ) in $84 \%$ yield $(359 \mathrm{mg}, 0.840 \mathrm{mmol}$ ) following the same procedure used for DMC ${ }^{2 \mathrm{Mes}}$, except that the crude product was purified by precipitation

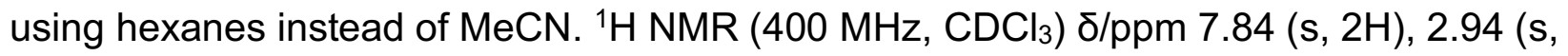
4H), $2.62(\mathrm{~s}, 8 \mathrm{H}), 2.48(\mathrm{~s}, 8 \mathrm{H}), 2.19(\mathrm{~s}, 6 \mathrm{H}), 1.35(\mathrm{~s}, 18 \mathrm{H}) \cdot{ }^{13} \mathrm{C} \mathrm{NMR}\left(101 \mathrm{MHz}, \mathrm{CDCl}_{3}\right)$ ర/ppm 171.21, 61.04, 56.47, 55.18, 50.68, 44.15, 28.94. HR-ESI-MS: [M+H] ${ }^{+} \mathrm{m} / \mathrm{z}$ : calcd for $\mathrm{C}_{22} \mathrm{H}_{47} \mathrm{~N}_{6} \mathrm{O}_{2}, 427.3760$; found 427.3761.

\section{1,7-dimethyl-4,10-bis(N-3,5-bis(trifluoromethyl)acetanilide)-1,4,7,10-tetra-}

azacyclododecane $\left(\mathrm{DMCy}^{\left.2 \mathrm{CF}_{3}\right)}\right.$. This compound was prepared from 1,7-dimethyl1,4,7,10-tetraazacyclododecane $(2)^{3-5} \quad(200 \mathrm{mg}, 1.00 \mathrm{mmol})$ and 2-chloro- $\mathrm{N}-3,5-$ bis(trifluoromethyl)acetanilide (1c) $(1.222 \mathrm{~g}, 4.00 \mathrm{mmol})$ in $95 \%$ yield $(702 \mathrm{mg}, 0.950$ mmol) following the procedure that was used for DMCy ${ }^{2 M e s}$. ${ }^{1} \mathrm{H}$ NMR $\left(400 \mathrm{MHz}, \mathrm{CDCl}_{3}\right)$

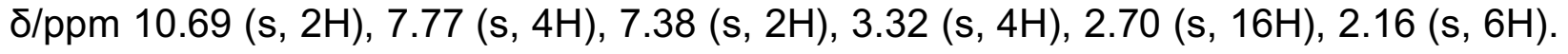
${ }^{13} \mathrm{C} \mathrm{NMR}\left(101 \mathrm{MHz}, \mathrm{CDCl}_{3}\right.$ ) $\delta / p p m$ 171.62, 139.98, 132.28 (q, $\left.J=33.3 \mathrm{~Hz}\right), 123.41$ (q, J $=272.7 \mathrm{~Hz}), 118.65(\mathrm{~d}, J=3.3 \mathrm{~Hz}), 117.12-116.35(\mathrm{~m}), 57.02(\mathrm{~d}, J=306.9 \mathrm{~Hz}), 55.66$, 51.65 (d, $J=816.2 \mathrm{~Hz}$ ), 45.19. HR-ESI-MS: [M] ${ }^{+} \mathrm{m} / \mathrm{z}$ : calcd for $\mathrm{C}_{30} \mathrm{H}_{34} \mathrm{~N}_{6} \mathrm{O}_{2} \mathrm{~F}_{12}, 738.2552$; found 738.2558 .

\section{1,7-dimethyl-4,10-bis( $N$-2,3,4,5,6-pentafluoroacetanilide)-1,4,7,10-tetra-}

azacyclododecane (DMCy ${ }^{2 \mathrm{C}_{65}} \mathrm{~F}_{5}$. This compound was prepared from 1,7-dimethyl1,4,7,10-tetraazacyclododecane $(2)^{3-5}$ (200 mg, $1.00 \mathrm{mmol}$ ) and 2-chloro- $\mathrm{N}-2,3,4,5,6$ pentafluoroacetanilide (1d) $(1.04 \mathrm{~g}, 4.00 \mathrm{mmol})$ in $33 \%$ yield $(216 \mathrm{mg}, 0.330 \mathrm{mmol})$ following the procedure as was used for DMCy ${ }^{2 \mathrm{Mes}}$. ${ }^{1} \mathrm{H} \mathrm{NMR}\left(400 \mathrm{MHz}, \mathrm{CDCl}_{3}\right) \delta / \mathrm{ppm}$ $11.63(\mathrm{~s}, 2 \mathrm{H}), 3.30(\mathrm{~s}, 4 \mathrm{H}), 2.66(\mathrm{~s}, 8 \mathrm{H}), 2.60(\mathrm{~s}, 8 \mathrm{H}), 2.19(\mathrm{~s}, 6 \mathrm{H}) .{ }^{13} \mathrm{C}$ NMR $(101 \mathrm{MHz}$, $\left.\mathrm{CDCl}_{3}\right) \delta / p p m$ 171.13, 143.42 (d, $\left.J=249.9 \mathrm{~Hz}\right), 139.99(\mathrm{~d}, J=253.6 \mathrm{~Hz}), 137.92(\mathrm{~d}, J=$ 
251.2 Hz), 112.85 (td, $J=15.2,4.1 \mathrm{~Hz}), 59.64,55.49,43.93,29.84$. HR-ESI-MS: $[M+H]^{+}$ $\mathrm{m} / \mathrm{z}$ : calcd for $\mathrm{C}_{26} \mathrm{H}_{29} \mathrm{~N}_{6} \mathrm{O}_{2} \mathrm{~F}_{10}, 647.2192$; found 647.2214 .

\section{1,7-dimethyl-4,10-bis(N-2,4,6-trimethylacetanilide)-1,4,7,10-tetraazacyclo-} dodecane nickel(II) hexafluorophosphate ([NiDMCy $\left.\left.{ }^{2 \mathrm{Mes}}\right]\left(\mathrm{PF}_{6}\right)_{2}\right) . \mathrm{NiCl}_{2}(65 \mathrm{mg}, 0.50$ mmol) and DMCy ${ }^{2 M e s}(275 \mathrm{mg}, 0.50 \mathrm{mmol})$ were combined in $20 \mathrm{~mL}$ of $\mathrm{CH}_{3} \mathrm{OH}$. The mixture was heated at reflux for $6 \mathrm{~h}$, after which time, the solvent was removed by rotary evaporation. The resulting pink solid was then dissolved in water and filtered through celite. Solid $\mathrm{NH}_{4} \mathrm{PF}_{6}(82 \mathrm{mg}, 1.0 \mathrm{mmol}$ ) was added to the filtrate to precipitate out the crude product, which was isolated and washed with water. This crude product was crystallized by vapor diffusion of $\mathrm{Et}_{2} \mathrm{O}$ into a concentrated $\mathrm{CH}_{3} \mathrm{CN}$ solution to afford purple crystals, which upon drying under the vacuum yielded $54 \mathrm{mg}$ of the desired product as a pink solid (Yield $=46 \%$ ). HR-ESI-MS: $\left[\mathrm{M}-\mathrm{PF}_{6}\right]^{+} \mathrm{m} / \mathrm{z}$ : calcd for $\mathrm{C}_{32} \mathrm{H}_{50} \mathrm{~F}_{6} \mathrm{~N}_{6} \mathrm{O}_{2} \mathrm{PNi}$, 753.2996; found, 753.2993. Anal. Calcd for $\mathrm{C}_{32} \mathrm{H}_{50} \mathrm{~F}_{12} \mathrm{~N}_{6} \mathrm{O}_{2} \mathrm{P}_{2} \mathrm{Ni}$ : C, 42.73; $\mathrm{H}, 5.60 ; \mathrm{N}$, 9.34. Found: $\mathrm{C}, 42.52 ; \mathrm{H}, 5.38 ; \mathrm{N}, 9.28$.

\section{1,7-dimethyl-4,10-bis(N-tert-butylacetamide)-1,4,7,10-tetraazacyclo-} dodecane nickel(II) hexafluorophosphate $\left(\left[\mathrm{NiDMCy}^{2 t \mathrm{Bu}}\right]\left(\mathrm{PF}_{6}\right)_{2}\right)$. This compound was prepared from $\mathrm{NiCl}_{2}(65 \mathrm{mg}, 0.50 \mathrm{mmol})$ and DMCy ${ }^{2 t \mathrm{Bu}}(213 \mathrm{mg}, 0.50 \mathrm{mmol})$ in $47 \%$ yield (102 $\mathrm{mg}, \quad 0.24 \mathrm{mmol}$ ) following the same procedure that was used for [NiDMCy $\left.{ }^{2 \mathrm{Mes}}\right]\left(\mathrm{PF}_{6}\right)_{2}$. HR-ESI-MS: $[\mathrm{M}+\mathrm{Na}]^{+} \mathrm{m} / \mathrm{z}$ : calcd for $\mathrm{C}_{22} \mathrm{H}_{46} \mathrm{~N}_{6} \mathrm{O}_{2} \mathrm{~F}_{12} \mathrm{P}_{2} \mathrm{NiNa}$, 797.2223; found, 797.2188. Anal. Calcd for $\mathrm{C}_{22} \mathrm{H}_{46} \mathrm{~N}_{6} \mathrm{O}_{2} \mathrm{~F}_{12} \mathrm{P}_{2} \mathrm{Ni}$ : C, 34.08; $\mathrm{H}, 5.98 ; \mathrm{N}$, 10.84. Found: C, 34.18; H, 5.84; N, 10.76.

\section{1,7-dimethyl-4,10-bis(N-3,5-bis(trifluoromethyl)acetanilide)-1,4,7,10-tetra-} azacyclododecane nickel(II) hexafluorophosphate ([NiDMCy $\left.\left.{ }^{2 \mathrm{CF}_{3}}\right]\left(\mathrm{PF}_{6}\right)_{2}\right)$. This compound was prepared from $\mathrm{NiCl}_{2}(65 \mathrm{mg}, 0.50 \mathrm{mmol})$ and $\mathrm{DMCy}^{2 \mathrm{CF}_{3}}(378 \mathrm{mg}, 0.50$ $\mathrm{mmol}$ ) in $51 \%$ yield $(282 \mathrm{mg}, 0.26 \mathrm{mmol}$ ) following the same procedure that was used for [NiDMCy ${ }^{2 \mathrm{Mes}}$ (PF $\left._{6}\right)_{2}$. HR-ESI-MS: $[\mathrm{M}+\mathrm{Na}]^{+} \mathrm{m} / \mathrm{z}$ : calcd for $\mathrm{C}_{30} \mathrm{H}_{34} \mathrm{~N}_{6} \mathrm{O}_{2} \mathrm{~F}_{24} \mathrm{P}_{2} \mathrm{NiNa}$, 
1109.1086; found, 1109.1088. Anal. Calcd for $\mathrm{C}_{30} \mathrm{H}_{34} \mathrm{~N}_{6} \mathrm{O}_{2} \mathrm{~F}_{24} \mathrm{P}_{2} \mathrm{Ni}$ : C, 33.14; $\mathrm{H}, 3.15 ; \mathrm{N}$, 7.73. Found: C, 32.88; $\mathrm{H}, 3.14 ; \mathrm{N}, 7.57$.

\section{1,7-dimethyl-4,10-bis( $N-2,3,4,5,6$-pentafluoroacetanilide)-1,4,7,10-tetra-}

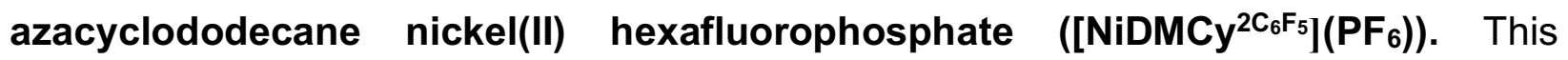
compound was prepared from $\mathrm{NiCl}_{2}(65 \mathrm{mg}, 0.5 \mathrm{mmol})$ and $\mathrm{DMCy}^{2 \mathrm{C}_{6} \mathrm{~F}_{5}}(327 \mathrm{mg}, 0.50$ $\mathrm{mmol}$ ) in $26 \%$ yield ( $91 \mathrm{mg}, 0.13 \mathrm{mmol}$ ) following the same procedure that was used for [NiDMCy $\left.{ }^{2 M e s}\right]\left(\mathrm{PF}_{6}\right)_{2}$. HR-ESI-MS: [M-H-PF $]^{+} \mathrm{m} / \mathrm{z}$ : calcd for $\mathrm{C}_{26} \mathrm{H}_{26} \mathrm{~N}_{6} \mathrm{O}_{2} \mathrm{~F}_{10} \mathrm{Ni}, 702.1311$; found, 702.1308. Anal. Calcd for $\mathrm{C}_{26} \mathrm{H}_{27} \mathrm{~N}_{6} \mathrm{O}_{2} \mathrm{~F}_{16} \mathrm{PNi}$ : C, 36.77; $\mathrm{H}, 3.20 ; \mathrm{N}, 9.90$. Found: C, 36.54; H, 2.96; N, 9.82.

\section{1,7-dimethyl-4-(N-2,4,6-trimethylacetanilide)-1,4,7,10-tetraazacyclo-} dodecane (DMCyMes). 1,7-dimethyl-1,4,7,10-tetraazacyclododecane (2) ${ }^{3-5}$ (200 mg, 1.00 mmol), 2-chloro- $N$-2,4,6-trimethylacetanilide (1a) $\left(212 \mathrm{mg}, 1.00 \mathrm{mmol}\right.$ ), and $\mathrm{K}_{2} \mathrm{CO}_{3}(166$ $\mathrm{mg}, 1.00 \mathrm{mmol}$ ) were suspended in $80 \mathrm{~mL}$ of $\mathrm{CH}_{3} \mathrm{OH}$. The mixture was heated at reflux for $12 \mathrm{~h}$ and then filtered through sintered glass to remove any solid materials. Distilled water ( $300 \mathrm{~mL}$ ) was added to the filtrate, followed by aliquots of $20 \%$ aqueous $\mathrm{HCl}$ until $\mathrm{pH}<2$. The aqueous phase was extracted three times with $30 \mathrm{~mL} \mathrm{Et}_{2} \mathrm{O}$ and the $\mathrm{pH}$ of the aqueous layer was then adjusted to $\mathrm{pH}>12$ with $6 \mathrm{M} \mathrm{NaOH}$. The aqueous layer was extracted with $\mathrm{CHCl}_{3}(7 \times 30 \mathrm{~mL})$ and the combined extracts were dried over $\mathrm{Na}_{2} \mathrm{SO}_{4}$. Removal of the solvent by rotary evaporation delivered the crude product as a yellow oil. Hexanes $(100 \mathrm{~mL})$ was added to the crude oil and the resulting mixture was sonicated for $30 \mathrm{~min}$, and filtered through celite. Evaporation of the hexanes under reduced pressure produced a white crystalline solid, which was dried further under vacuum to deliver 245 $\mathrm{mg}$ of the desired product (Yield $=65 \%) .{ }^{1} \mathrm{H}$ NMR $\left(400 \mathrm{MHz}, \mathrm{CDCl}_{3}\right) \delta / \mathrm{ppm} 9.56(\mathrm{~s}, 1 \mathrm{H})$, $6.86(\mathrm{~s}, 2 \mathrm{H}), 3.27(\mathrm{~s}, 2 \mathrm{H}), 2.73-2.60(\mathrm{br}, 8 \mathrm{H}), 2.56-2.43(\mathrm{br}, 8 \mathrm{H}), 2.24(\mathrm{~s}, 3 \mathrm{H}), 2.23(\mathrm{~s}$,

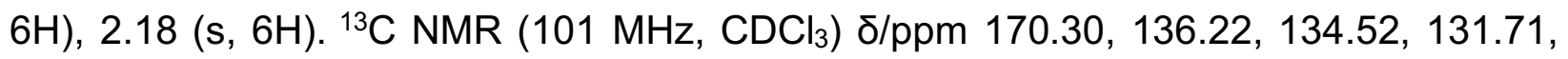
129.02, 57.05, 54.88, 53.22, 46.01, 45.35, 44.35, 21.05, 18.67. HR-ESI-MS: [M+H] m/z: calcd for $\mathrm{C}_{21} \mathrm{H}_{38} \mathrm{~N}_{5} \mathrm{O}, 376.3071$; found 376.3076 . 


\section{1,7-dimethyl-4-(N-2,4,6-trimethylacetanilide)-1,4,7,10-tetraazacyclo-}

dodecane Nickel(II) chloride hexafluorophosphate ([Ni(DMCyMes)(Cl)](PF 6$)$ ). $\mathrm{NiCl}_{2}$ (85 mg, $0.66 \mathrm{mmol}$ ) and DMCyMes $(245 \mathrm{mg}, 0.65 \mathrm{mmol}$ ) were combined in $20 \mathrm{~mL}$ of $\mathrm{CH}_{3} \mathrm{OH}$. The mixture was heated at reflux for $6 \mathrm{~h}$, and then filtered through celite. Removal of the solvent by rotary evaporation yielded a blue solid, which was then crystallized via vapor diffusion of $\mathrm{Et}_{2} \mathrm{O}$ into a concentrated $\mathrm{CH}_{3} \mathrm{OH}$ solution to give $228 \mathrm{mg}$ of blue crystals that were comprised of $\left[\mathrm{Ni}\left(\mathrm{DMCy}{ }^{\mathrm{Mes}}\right)(\mathrm{Cl})\right] \mathrm{Cl}(\mathrm{Yield}=69 \%) .{ }^{11}$

The $228 \mathrm{mg}(0.45 \mathrm{mmol})$ of [Ni(DMCyMes)(Cl)]Cl was dissolved in $20 \mathrm{~mL}$ of $\mathrm{CH}_{3} \mathrm{CN}$ and combined with a stoichiometric amount of $\mathrm{ThPF}_{6}(132 \mathrm{mg}, 0.45 \mathrm{mmol})$. The resulting solution was heated at reflux for $6 \mathrm{~h}$, cooled to room temperature and then filtered through celite to remove precipitated $\mathrm{TICl}$. Concentration of the filtrate by rotary evaporation delivered a blue solid, which was crystallized via vapor diffusion of $\mathrm{Et}_{2} \mathrm{O}$ into a concentrated $\mathrm{CH}_{3} \mathrm{CN}$ solution to afford blue crystals, which upon drying under vacuum yielded $140 \mathrm{mg}$ of the titled complex (Yield $=60 \%$. HR-ESI-MS: $\left[\mathrm{M}-\mathrm{PF}_{6}\right]^{+} \mathrm{m} / \mathrm{z}$ : calcd for $\mathrm{C}_{21} \mathrm{H}_{37} \mathrm{~N}_{5} \mathrm{OCINi}$, 468.2040; found, 468.2040. Anal. Calcd for $\mathrm{C}_{21} \mathrm{H}_{37} \mathrm{~N}_{5} \mathrm{OCIF} 6 \mathrm{PNi} \cdot\left(\mathrm{H}_{2} \mathrm{O}+\right.$ $\mathrm{CH}_{3} \mathrm{CN}$ ): C, 41.00; H, 6.28; N, 12.47. Found: C, 40.89; H, 6.50; N, 12.61.

\section{1,4,7-trimethyl-10-(N-2,4,6-trimethylacetanilide)-1,4,7,10-tetraazacyclo-} dodecane (TrMCyMes one-arm ligand). 1,4,7-trimethyl-1,4,7,10-tetraazacyclododecane $(4)^{6}$ (107 mg, $0.50 \mathrm{mmol}$ ), 2-chloro- $\mathrm{N}-2,4,6$-trimethylacetanilide (1a) (127 mg, $0.60 \mathrm{mmol}$ ), and $\mathrm{K}_{2} \mathrm{CO}_{3}(138 \mathrm{mg}, 1.0 \mathrm{mmol})$ were dissolved in $20 \mathrm{~mL}$ of $\mathrm{CH}_{3} \mathrm{CN}$ and heated at reflux for $12 \mathrm{~h}$. After cooling the solution to room temperature, the resulting solution was filtered through sintered glass to remove any solid materials. Distilled water $(100 \mathrm{~mL})$ was added to the solution, and aliquots of $20 \%$ aqueous $\mathrm{HCl}$ were added until $\mathrm{pH}<2$. The resulting solution was extracted three times with $30 \mathrm{~mL}$ of $\mathrm{Et}_{2} \mathrm{O}$. Aliquots of $6 \mathrm{M} \mathrm{NaOH}$ were then added to the aqueous layer until $\mathrm{pH}>12$. The aqueous layer was then extracted with $\mathrm{CHCl}_{3}(7 \times 30 \mathrm{~mL})$ and the combined extracts were dried over $\mathrm{Na}_{2} \mathrm{SO}_{4}$. Removal of the solvent by rotary evaporation delivered the crude product as a yellow oil. Hexanes (100 
$\mathrm{mL}$ ) was added to the crude oil and the resulting mixture was sonicated for $30 \mathrm{~min}$, and filtered through celite. Evaporation of the hexanes under reduced pressure produced a white crystalline solid, which was dried further under vacuum to deliver $125 \mathrm{mg}$ of the desired product $($ Yield $=63 \%) .{ }^{1} \mathrm{H}$ NMR $\left(400 \mathrm{MHz}, \mathrm{CDCl}_{3}\right) \delta / p p m 10.20(\mathrm{~s}, 1 \mathrm{H}), 6.87(\mathrm{~s}$, 2H), $3.29(\mathrm{~s}, 2 \mathrm{H}), 2.64(\mathrm{br}, 8 \mathrm{H}), 2.51(\mathrm{br}, 8 \mathrm{H}), 2.25(\mathrm{~s}, 3 \mathrm{H}), 2.21(\mathrm{~s}, 6 \mathrm{H}), 2.13(\mathrm{~s}, 3 \mathrm{H}), 2.11$ (s, 3H). ${ }^{13} \mathrm{C}$ NMR $\left(101 \mathrm{MHz}, \mathrm{CDCl}_{3}\right) \delta / p p m$ 170.93, 136.23, 135.02, 132.32, 128.88, $58.73,56.84,56.45,55.82,54.65,45.02,44.38,21.09,18.63$. HR-ESI-MS: [M] ${ }^{+}$m/z: calcd for $\mathrm{C}_{22} \mathrm{H}_{39} \mathrm{~N}_{5} \mathrm{O}$, 389.3155; found, 389.3162.

\section{1,4,7-trimethyl-10-(N-2,4,6-trimethylacetanilide)-1,4,7,10-tetraazacyclo-}

dodecane Nickel(II) chloride ([Ni(TrMCyMes)(Cl)]Cl). $\mathrm{NiCl}_{2}(22 \mathrm{mg}, 0.17 \mathrm{mmol})$ and TrMCyMes $\left(65 \mathrm{mg}, 0.17 \mathrm{mmol}\right.$ ) were mixed in $15 \mathrm{~mL}$ of $\mathrm{CH}_{3} \mathrm{OH}$. The mixture was heated at reflux for $6 \mathrm{~h}$, cooled to room temperature and then filtered through celite. Removal of the solvent by rotary evaporation gave a green solid. The resulting pink solid was then dissolved in water and filtered through celite. The mixture was refluxed for $6 \mathrm{~h}$, after which was filtered through celite. Solvent was removed to give green solid, which was then crystallized via vapor diffusion of $\mathrm{Et}_{2} \mathrm{O}$ into a concentrated $\mathrm{CH}_{3} \mathrm{OH}$ solution yield $69 \mathrm{mg}$ of the title compound as green crystals (Yield $=80 \%$ ). HR-ESI-MS: $[\mathrm{M}-\mathrm{Cl}]^{+} \mathrm{m} / \mathrm{z}$ : calcd for $\mathrm{C}_{22} \mathrm{H}_{39} \mathrm{~N}_{5} \mathrm{OCINi}$, 482.2197; found, 482.2202. Anal. Calcd for $\mathrm{C}_{22} \mathrm{H}_{39} \mathrm{~N}_{5} \mathrm{OCl}_{2} \mathrm{Ni} \cdot\left(2 \mathrm{H}_{2} \mathrm{O}\right): \mathrm{C}$, 47.59; H, 7.80; N, 12.61. Found: C, 47.98; H, 7.40; N, 12.64 . 
Table S1. Crystallographic data for DMC $y^{2 \mathrm{Mes}}$.

\begin{tabular}{ll}
\hline & DMCy ${ }^{2 M e s}$ \\
\hline Empirical Formula & $\mathrm{C}_{32} \mathrm{H}_{50} \mathrm{~N}_{6} \mathrm{O}_{2}$ \\
Formula Weight & 550.78 \\
Temperature & $200(2) \mathrm{K}$ \\
Wavelength & $0.71073 \AA$ \\
Crystal System & Triclinic \\
Space Group & $\mathrm{P}-1$ \\
$a$ & $7.9099(19) \AA$ \\
$b$ & $8.704(2) \AA$ \\
$c$ & $12.658(3) \AA$ \\
$\alpha$ & $101.385(4)^{\circ}$ \\
$\beta$ & $101.145(4)^{\circ}$ \\
$\gamma$ & $105.893(4)^{\circ}$ \\
Volume & $792.9(3) \AA^{3}$ \\
$Z$ & 1 \\
Dcalc & $1.154 \mathrm{mg}^{\circ} \mathrm{m}^{3}$ \\
Absorption coefficient & $0.073 \mathrm{~mm}^{-1}$ \\
F(000) & 300 \\
Crystal Size & $0.44 \times 0.43 \times 0.17 \mathrm{~mm}^{3}$ \\
$2 \theta$ range & $1.70^{\circ}-28.37^{\circ}$ \\
Index ranges & $-10 \leq h \leq 10,-11 \leq k \leq 11,-16 \leq I \leq 16$ \\
Reflections & 10948 \\
Unique & 3962 \\
$R$ (int) & 0.0288 \\
$R 1$ & 0.0499 \\
wR2 & 0.1400 \\
\hline
\end{tabular}


Table S2. Crystallographic data for $\left[\mathrm{Ni}\left(\mathrm{DMC}^{2 \mathrm{Mes}}\right)\right]\left(\mathrm{PF}_{6}\right)_{2}$.

\begin{tabular}{|c|c|}
\hline & {$\left[\mathrm{Ni}\left(\mathrm{DMCy}^{2 \mathrm{Mes}}\right)\right]\left(\mathrm{PF}_{6}\right)_{2} \cdot 2 \mathrm{MeCN}$} \\
\hline Empirical Formula & $\mathrm{C}_{38} \mathrm{H}_{59} \mathrm{~F}_{12} \mathrm{~N}_{9} \mathrm{NiO}_{2} \mathrm{P}_{2}$ \\
\hline Formula Weight & 981.53 \\
\hline Temperature & $200(2) \mathrm{K}$ \\
\hline Wavelength & $0.71073 \AA$ \\
\hline Crystal System & Monoclinic \\
\hline Space Group & $P 2_{1} / n$ \\
\hline a & 14.039 (4) A \\
\hline$b$ & 13.195 (4) $\AA$ \\
\hline$c$ & 25.867 (8) $\AA$ \\
\hline$\alpha$ & $90^{\circ}$ \\
\hline$\beta$ & $94.717(5)^{\circ}$ \\
\hline$\gamma$ & $90^{\circ}$ \\
\hline Volume & $4775(2) \AA^{3}$ \\
\hline Z & 4 \\
\hline $\mathrm{D}_{\text {calc }}$ & $1.365 \mathrm{mg} / \mathrm{m}^{3}$ \\
\hline Absorption coefficient & $0.559 \mathrm{~mm}^{-1}$ \\
\hline$F(000)$ & 300 \\
\hline Crystal Size & $0.37 \times 0.28 \times 0.23 \mathrm{~mm}^{3}$ \\
\hline $2 \theta$ range & $1.60^{\circ}-28.28^{\circ}$ \\
\hline Index ranges & $-18 \leq h \leq 18,-17 \leq k \leq 17,-34 \leq / \leq 34$ \\
\hline Reflections & 64392 \\
\hline Unique & 11842 \\
\hline$R$ (int) & 0.0376 \\
\hline$R 1$ & 0.0540 \\
\hline $\mathrm{w} R 2$ & 0.1468 \\
\hline
\end{tabular}


Table S3. Crystallographic data for $\left[\mathrm{Ni}\left(\mathrm{DMC}^{2 \mathrm{tBu}}\right)\right]\left(\mathrm{PF}_{6}\right)_{2}$.

\begin{tabular}{ll}
\hline & {$\left[\mathrm{Ni}\left(\mathrm{DMCy}^{2 \mathrm{tBu}}\right)\right]\left(\mathrm{PF}_{6}\right)_{2} \bullet \mathrm{MeCN}$} \\
\hline Empirical Formula & $\mathrm{C}_{24} \mathrm{H}_{49} \mathrm{~F}_{12} \mathrm{~N}_{7} \mathrm{NiO}_{2} \mathrm{P}_{2}$ \\
Formula Weight & 816.35 \\
Temperature & $200(2) \mathrm{K}$ \\
Wavelength & $0.71073 \AA$ \\
Crystal System & Tetragonal \\
Space Group & $14 / \mathrm{m}$ \\
$a$ & $25.203(4) \AA$ \\
$b$ & $25.204(4) \AA$ \\
$c$ & $12.848(4) \AA$ \\
$\alpha$ & $90^{\circ}$ \\
$\beta$ & $90^{\circ}$ \\
$\gamma$ & $90^{\circ}$ \\
Volume & $8161(3) \AA^{3}$ \\
$Z$ & 8 \\
Dcalc & $1.329 \mathrm{mg} / \mathrm{m}^{3}$ \\
Absorption coefficient & $0.639 \mathrm{~mm}^{-1}$ \\
F(000) & 3392 \\
Crystal Size & $0.34 \times 0.17 \times 0.14 \mathrm{~mm}^{3}$ \\
$2 \theta$ range & $1.62^{\circ}-28.29^{\circ}$ \\
Index ranges & $-33 \leq h \leq 33,-33 \leq k \leq 33,-17 \leq I \leq 17$ \\
Reflections & 56126 \\
Unique & 5290 \\
$R$ (int) & 0.0344 \\
$R 1$ & 0.0562 \\
wR2 & 0.1624 \\
\hline
\end{tabular}


Table S4. Crystallographic data for $\left[\mathrm{Ni}\left(\mathrm{DMCy}^{2 \mathrm{CF} 3}\right)\right]\left(\mathrm{PF}_{6}\right)_{2}$.

\begin{tabular}{ll}
\hline & {$\left[\mathrm{Ni}\left(\mathrm{DMCy}^{2 \mathrm{CF} 3}\right)\right]\left(\mathrm{PF}_{6}\right)_{2} \cdot 3 \mathrm{MeCN}$} \\
\hline Empirical Formula & $\mathrm{C}_{36} \mathrm{H}_{43} \mathrm{~F}_{24} \mathrm{~N}_{9} \mathrm{NiO}_{2} \mathrm{P}_{2}$ \\
Formula Weight & 1210.44 \\
Temperature & $200(2) \mathrm{K}$ \\
Wavelength & $0.71073 \AA$ \\
Crystal System & Monoclinic \\
Space Group & $P 21 / n$ \\
$a$ & $12.376(7) \AA$ \\
$b$ & $12.816(7) \AA$ \\
$c$ & $31.611(18) \AA$ \\
$\alpha$ & $90^{\circ}$ \\
$\beta$ & $91.801(9)^{\circ}$ \\
$\gamma$ & $90^{\circ}$ \\
Volume & $5012(5) \AA^{3}$ \\
$Z$ & 4 \\
D & $1.604 \mathrm{mg} / \mathrm{m}^{3}$ \\
Absorption coefficient & $0.583 \mathrm{~mm} \mathrm{~m}^{-1}$ \\
$\mathrm{~F}(000)$ & 2448 \\
Crystal Size & $0.37 \times 0.23 \times 0.11 \mathrm{~mm}^{3}$ \\
$2 \theta$ range & $1.71^{\circ}-28.32^{\circ}$ \\
Index ranges & $-16 \leq h \leq 16,-17 \leq k \leq 17,-42 \leq I \leq 41$ \\
Reflections & 67721 \\
Unique & 12464 \\
$R$ (int) & 0.0368 \\
$R 1$ & 0.0704 \\
wR2 & 0.2039 \\
\hline
\end{tabular}


Table S5. Crystallographic data for $\left[\mathrm{Ni}\left(\mathrm{DMC}^{2 \mathrm{2C6F5}}\right)\right]\left(\mathrm{PF}_{6}\right)_{2}$.

\begin{tabular}{ll}
\hline & {$\left[\mathrm{Ni}\left(\mathrm{DMCy}^{2 \mathrm{C6F5}}\right)\right]\left(\mathrm{PF}_{6}\right)_{2^{\bullet}}$} \\
\hline Empirical Formula & $\mathrm{C}_{26} \mathrm{H}_{27} \mathrm{~F}_{16} \mathrm{~N}_{6} \mathrm{NiO}_{2} \mathrm{P}$ \\
Formula Weight & 849.21 \\
Temperature & $200(2) \mathrm{K}$ \\
Wavelength & $0.71073 \AA$ \\
Crystal System & Monoclinic \\
Space Group & $P 21 / c$ \\
$a$ & $21.622(4) \AA$ \\
$b$ & $18.598(3) \AA$ \\
$c$ & $19.779(3) \AA$ \\
$\alpha$ & $90^{\circ}$ \\
$\beta$ & $110.467(3)^{\circ}$ \\
$\gamma$ & $90^{\circ}$ \\
Volume & $7452(5) \AA^{3}$ \\
$Z$ & 8 \\
Dcalc & $1.514 \mathrm{mg}^{\circ} / \mathrm{m}^{3}$ \\
Absorption coefficient & $0.677 \mathrm{~mm}^{-1}$ \\
F(000) & 3424 \\
Crystal Size & $0.33 \times 0.26 \times 0.17 \mathrm{~mm}^{3}$ \\
$2 \theta$ range & $1.55^{\circ}-28.30^{\circ}$ \\
Index ranges & $-28 \leq h \leq 28,-24 \leq k \leq 24,-26 \leq I \leq 26$ \\
Reflections & 86794 \\
Unique & 18500 \\
$R$ (int) & 0.0424 \\
$R 1$ & 0.0668 \\
wR2 & 0.1748 \\
\hline
\end{tabular}


Table S6. Crystallographic data for $\left[\mathrm{Ni}\left(\mathrm{DMC}^{\mathrm{Mes}}\right)(\mathrm{Cl})\right]\left(\mathrm{PF}_{6}\right)$.

\begin{tabular}{ll}
\hline & {$\left[\mathrm{Ni}\left(\mathrm{DMCy}^{\mathrm{Mes}}\right)(\mathrm{Cl})\right]\left(\mathrm{PF}_{6}\right) \cdot \mathrm{CH}_{3} \mathrm{CN}$} \\
\hline Empirical Formula & $\mathrm{C}_{23} \mathrm{H}_{40} \mathrm{CIF}_{6} \mathrm{~N}_{6} \mathrm{NiOP}$ \\
Formula Weight & 655.74 \\
Temperature & $200(2) \mathrm{K}$ \\
Wavelength & $0.71073 \AA$ \\
Crystal System & Monoclinic \\
Space Group & $P 21 / \mathrm{c}$ \\
$a$ & $11.682(4) \AA$ \\
$b$ & $13.171(4) \AA$ \\
$c$ & $20.128(6) \AA$ \\
$\alpha$ & $90^{\circ}$ \\
$\beta$ & $104.369(5)^{\circ}$ \\
$\gamma$ & $90^{\circ}$ \\
Volume & $3000.1(15) \AA^{3}$ \\
$Z$ & 4 \\
$D_{\text {calc }}$ & $1.452 \mathrm{mg} / \mathrm{m}^{3}$ \\
Absorption coefficient & $0.854 \mathrm{~mm}^{-1}$ \\
$\mathrm{~F}(000)$ & 1368 \\
Crystal Size & $0.34 \times 0.20 \times 0.10 \mathrm{~mm}^{3}$ \\
$2 \theta$ range & $1.80^{\circ}-28.31^{\circ}$ \\
Index ranges & $-15 \leq h \leq 15,-17 \leq k \leq 17,-26 \leq I \leq 26$ \\
Reflections & 40487 \\
Unique & 7468 \\
$R$ (int) & 0.0293 \\
$R 1$ & 0.0351 \\
wR2 & 0.0924 \\
\hline
\end{tabular}


Table S7. Crystallographic data for $\left[\mathrm{Ni}\left(\mathrm{TrMCy}^{\mathrm{Mes}}\right)(\mathrm{Cl})\right] \mathrm{Cl}$.

\begin{tabular}{ll}
\hline & {$\left[\mathrm{Ni}\left(\mathrm{TrMC}^{\mathrm{Mes}}\right)(\mathrm{Cl})\right] \mathrm{Cl}$} \\
\hline Empirical Formula & $\mathrm{C}_{22} \mathrm{H}_{39} \mathrm{Cl}_{2} \mathrm{~N} 5 \mathrm{NiO}$ \\
Formula Weight & 519.19 \\
Temperature & $200(2) \mathrm{K}$ \\
Wavelength & $0.71073 \AA$ \\
Crystal System & Monoclinic \\
Space Group & $P 21 / \mathrm{c}$ \\
$a$ & $11.7528(11) \AA$ \\
$b$ & $13.3236(12) \AA$ \\
$c$ & $16.2943(15) \AA$ \\
$\alpha$ & $90^{\circ}$ \\
$\beta$ & $102.8140^{\circ}$ \\
$\gamma$ & $90^{\circ}$ \\
Volume & $2488.0(4) \AA^{3}$ \\
$Z$ & 4 \\
$D_{\text {calc }}$ & $1.386 \mathrm{mg}^{3} \mathrm{~m}^{3}$ \\
Absorption coefficient & $1.018 \mathrm{~mm}^{-1}$ \\
F(000) & 1104 \\
Crystal Size & $0.19 \times 0.19 \times 0.09 \mathrm{~mm}^{3}$ \\
$2 \theta$ range & $1.78^{\circ}-27.45^{\circ}$ \\
Index ranges & $-15 \leq h \leq 15,-17 \leq k \leq 16,-21 \leq I \leq 21$ \\
Reflections & 24156 \\
Unique & 5683 \\
$R($ int) & 0.0421 \\
$R 1$ & 0.0416 \\
wR2 & 0.1022 \\
\hline
\end{tabular}




\section{References}

1) Shriver, D. F.; Drezdzon, M. A., The manipulation of air-sensitive compounds. 1986, New York: Wiley.

2) Pangborn, A. B.; Giardello, M. A.; Grubbs, R. H.; Rosen, R. K., Timmers, F. J. "Safe and Convenient Procedure for Solvent Purification" Organometallics, 1996, 15, 15181520.

3) Kovacs, Z.; Sherry, A. D. "A general synthesis of 1,7-disubstituted 1,4,7,10tetraazacyclododecanes" J. Chem. Soc., Chem. Commun., 1995, 185-186.

4) Kovacs, Z.; Sherry, A. D. "pH-Controlled Selective Protection of Polyaza Macrocycles" Synthesis, 1997, 759-763.

5) Piersanti, G.; Varrese, M. A.; Fusi, V.; Giorgi, L.; Zappia, G. "Short and straightforward synthesis of 1,7-dimethyl-1,4,7,10-tetraazacyclododecane" Tetrahedron Lett. 2010, 51, 3436-3438.

6) Ohashi, M.; Konkol, M.; Del Rosal, I.; Poteau, R.; Maron, L.; Okuda, J. "' J. Am. Chem. Soc., 2008, 130, 6920-6921.

7) Bambirra, S.; van Leusen, D.; Tazelaar, C. G. J.; Meetsma, A.; Hessen, B. "Rare Earth Metal Alkyl Complexes with Methyl-Substituted Triazacyclononane-amide Ligands: Ligand Variation and Ethylene Polymerization Catalysis" Organometallics, 2007, 26, 1014-1023.

8) Jaeheung, C.; Ritimukta, S.; Jamespandi, A.; Sung Yeon, K.; Minoru, K.; Takashi, O.; Edward, I. S.; Wonwoo, N. "Geometric and electronic structure and reactivity of a mononuclear 'side-on' nickel(III)-peroxo complex" Nature Chemistry, 2009, 1, 568572.

9) Sheldrick, G. "A Short History of SHELX" Acta Crystallographica Section A, 2008, 64, 112-122.

10) Spek, A. "Single-crystal structure validation with the program PLATON" J. Appl. Crystallogr., 2003, 36, 7-13.

11) The composition and structure of $\left[\mathrm{Ni}\left(\mathrm{DMC} \mathrm{y}^{\mathrm{Mes}}\right)(\mathrm{Cl})\right] \mathrm{Cl}$ was verified by $\mathrm{x}$-ray crystallography. 